\title{
The Determinants of Corporate Tax Aggressiveness
}

\author{
IDA FARIDA ADI PRAWIRA ${ }^{1}$, JEFFRY SANDRIA ${ }^{2}$ \\ ${ }^{1}$ Accounting Departement, UNIVERSITAS PENDIDIKAN INDONESIA. E-mail: ida.farida@upi.edu \\ ${ }^{2}$ Accounting Departement, UNIVERSITAS PENDIDIKAN INDONESIA.
}

\begin{abstract}
Tax-related research is a matter of great interest to researchers over the past decade. Several researchers have attempted to study factors that affect corporate tax aggressiveness. Referring to 27 Real Estates and Property sample of firms from Indonesia, this study investigates a relation among executive characteristics, firm size, leverage, profitability, and corporate tax aggressiveness. Applying Cash ETR (Effective Tax Rate) as an appropriate measures of tax aggressiveness, and use multiple regression model, the study found a strong evidence that executive characteristics, firm size, and profitability are negatively correlated with the likelihood of tax aggressiveness. Meanwhile, leverage has a positive correlation to tax aggressiveness. The results revealed that the initial hypothesis ( $\mathrm{Ho}$ ) was accepted. However, there are many other factors that can influence corporate tax aggressiveness that were not examined in this study. For future research, it is expected to examine these other factors. Based on the results of this study, companies must pay more attention to the characteristics of executives in carrying out tax aggressiveness due to the fact that the higher the level of corporate risk, the smaller corporate tax aggressiveness. Although this study gradually builds upon recent studies about corporate tax aggressiveness, it brings a groundbreaking comparative assessment of executive characteristics, firm size, leverage, profitability, and corporate tax aggressiveness.
\end{abstract}

Keywords: Executive Characteristics, Firm Size, Leverage, Profitability, Corporate Tax Aggressiveness

\section{JEL Classification: J}




\section{Introduction}

Tax influences on corporations have largely been considered within a framework where taxes are involuntary payments affecting finance and investment choice on margin (Desai \& Dharmapala, 2006). Such a framework does not dismiss the role of taxes but it views them as inescapable environmental factors that must be weighed against a variety of other factors e.g. those emphasized in the Modigliani and Miller (1963),Waworuntu and Hadisaputra (2016) framework for understanding corporate financial decisions. Consequently, most scholarly attention has been focused on how taxes change capital structures, dividend or investment decisions. Account of rising corporate tax aggressiveness suggests that a pure compliance function no longer characterizes the way corporations and managers consider their corporate tax obligation (Desai \& Dharmapala, 2006; Christina, 2017). This kind of assessment typically points to aggregate measures of tax aggressiveness including measures of growing difference between income reported to tax authorities and capital markets, declination of effective tax rates on public financial statements and growing share of firms with no tax liability. Regarding this, Prawira(2017) reports effective tax rate reductions in the 58 manufacturing company from an average of 3,04\% in 2013 to 1,99\% in 2014.

Considering those facts, it comes to question "what are the determinant factors?". Many studies have been through to examine it showing that the complexity of tax legislation often lies in the diversity of interpretations that sometimes contradict with spirit of the law (Bond et al., 2002). Indeed, some studies by Sikka and Haslam (2007) have confirmed that the various interpretations of the tax law letter are the tax aggressiveness source. In addition, the work of Duff (2009) also showed that some forms of tax aggressiveness are clearly acceptable while others remain ambiguous. Although some highly sophisticated optimization techniques designed to reduce the tax burden, and they could be considered an illegal activity. Alm et al. (1990) found that tax aggressiveness can take various legal and illegal forms, while it is influenced by the incentives created by the tax system.

In the similar vein, a study conducted by Mayta and Sukartha (2016), tax aggressiveness done by a company was based on the existence of policies of corporate leaders, and certainly they have different characteristics that will affect their decisions. Top executives have the responsibility to various existing tax aggressiveness practices in an enterprise, such as a CEO who can influence practice of tax aggressiveness by regulating corporate taxation "(Dyreng et al., 2010). Crocker \& Slemrod (2005) and Dharmapala \& Desai (2009) link corporate tax aggressiveness with agency costs in which they emphasize that managers who are not necessarily owners of the firms choose the level of tax aggressiveness. Since tax sheltering is obscured from the tax authority by its nature, it is obscured from outside investors as well. However, investors can be skeptical whether the tax sheltering aims to enhance shareholder value or it is motivated by managers' self-interests. If investors believe that the latter factor outweighs the former factor, tax sheltering reduces firm value among publicly-traded (listed) companies through a drop in stock prices.

The question of our work consists of examining determinants of tax aggressiveness within corporate groups, such as the means by which the corporate groups can use in order to reduce their tax liabilities. In the same way, our objective is to evaluate the impacts of firm size, profitability, leverage, and executive characteristics on corporate tax aggressiveness determinants, while using the effective tax rate (ETR) as a tax aggressiveness measure. The importance of our research appears at several levels; In the first place, our study is the first in Indonesia in which it studies the determinants of tax aggressiveness within the corporate groups. Secondly, this study contributes to development of research on the taxation of corporate groups (Slemrod \& Wilson, 2009; Slemrod, 2001; Richardson et al., 2013a; and Richardson et al., 2013b), and this is through the construction of a tax aggressiveness measure within groups, at the last, our study provides a global view on how Indonesian listed groups engage in tax aggressiveness.

As research samples our empirical evidence study involved 27 corporate groups listed on the Indonesia Stock Exchange, for a period of 8 years, from 2009 to 2016. This study consists of analyzing consolidated financial statements and information notes relating to financial transactions of the 
corporate groups. In fact, the results of this study (multiple regression method) showed that firm size, profitability, leverage, and executive characteristics were significantly associated with the corporate tax aggressiveness.

The following parts of this paper are organized as follows: Section 2 presents a brief review of literature under the topic of corporate tax aggressiveness and also develops our hypotheses; Section 3 discusses the research design, sample selection, and summary statistics; Section 4 summarizes and analyzes the empirical results. Finally, Section 5 concludes and limitation of the paper.

\section{Literature Review and Hypotheses Development}

Several authors have addressed the issue of group taxation by examining tax management practices and their impact on group performance. The literature in tax aggressiveness is classified into two groups (Orihara, 2015). One group of research proposed by Allingham and Sandmo (1972) who interpret tax sheltering as an attempt to shift income from governments to individuals. These studies treat tax aggressiveness as one of various activities that increases after-tax profits. Thus, individuals engage in tax aggressiveness as long as tax costs, which depend on the frequency of tax audits and the magnitude of tax penalties are lower than tax benefits. A characteristic of this line of literature is that they presume that those who evade taxes are individuals. Crocker and Slemrod (2005) argue that this framework is not suitable to analyze corporate tax aggressiveness it is due to agency conflicts resulting from the separation of ownership and control in corporations are not considered in this framework.

The second group considered as relatively new literature relates this agency dimension to corporate tax aggressiveness. It is mentioned that tax aggressiveness refers to the most extreme subset of tax aggressiveness activities that are "pushing the envelope of tax law" (Hanlon and Heitzman, 2010; p.137). Tax aggressive activities are more likely to be scrutinized by tax authorities. When successfully challenged, firms may be subject to large penalties (Wilson, 2009). Besides, firms engaging in tax aggressive behavior also bear potential reputational costs. In particular, as argued by Bankman (2004) and Hanlon and Slemrod (2009), if a firm is publicly revealed to be tax aggressive, it runs some risks of being labeled as a "poor corporate citizen." Consistent with this notion, Hanlon and Slemrod (2009) find that stock markets react negatively to public revelation of tax sheltering. Austin and Wilson (2015) find that firms with valuable consumer brands have higher effective tax rates thus lower tax aggressiveness than firms without valuable consumer brands. In addition, in Graham et al.'s (2014) survey, $69 \%$ of tax executives report that the potential loss of reputation is an important factor in terms of determining why they do not participate in tax planning. Regarding this, Gallemore et al. (2014) do not find support for reputational effects playing a significant role in lost sales, media reputation, or CEO, CFO, or auditor turnover. However, Graham et al. (2014) question the ability of the data and methodology used by Gallemore et al. (2014) to ascertain the importance of reputational impact of tax aggressiveness.

\subsection{Firm size and Firm Value (Profitability)}

Firm value represents assets owned by a company. It is crucial because it describes the prosperity of the business owners. The manager being the representative of the business owners is responsible for achieving optimal maximization of firm value which forms the fundamental objective of any organization. In addition, a high firm value indicates that the company is prosperous and hence the shareholders' wealth is maximized. The prosperity level of the shareholders and investors can be reflected in the firm value. It is an indicator used to assess the performance of a company. Furthermore, investors also perceive the company through its firm value which is related to the stock price. According to Ftouhi, Ayed and Zemzem (2010), the high stock price will make a higher firm value. Specifically, firm value may be measured from two perspectives: from the point of view of accounting measure of profitability: return on assets (ROA), return on equity (ROE), Tobin's $Q$, net profit margin; and from the stock market perspective, using share prices from the Stock Exchange market. 


\subsection{Leverage}

The leverage ratio is widely used to measure portion of long term debts towards total assets of business organization's activities. It means the capability of a business organization in financing depends on its total assets with long-term debt (Danielova \& Sarka, 2011). Ngadiman \& Puspitasari (2014) argued that the policies taken by the company have a significant role to the level of corporate tax aggressiveness such as determining the company's financial in the form of debt or leverage. Adelina (2012) highlighted that leverage revision is a ratio that explains the amount of debt owned by the company to finance its operating activities, so the additional debt will be more rescued by the company and it will be reduced profit before taxable. By doing so, payable tax of the company becomes reduced.

\subsection{Executive Characteristics}

It might be difficult to imagine a top executive having an individual effect on the firm's tax aggressiveness (Dyreng et al., 2010). In fact, the typical CEO is almost never a tax expert. While the typical CEO is unlikely to understand the ins and outs of common tax strategies, he/she likely understands the competitive nature of his/her industry and the potential for expansion to generate operational economies of scale. Thus, it is reasonable that a CEO could affect the firm's operational and financial strategies but perhaps it less influences the firm's tax aggressiveness activities.

Individual executives play a significant role in determining level of tax aggressiveness that firms undertake automatically becoming incremental to characteristics of the firm (Dyreng et al., 2010). Analyzing executive effects in event time shows consistent results with executive-specific tax aggressiveness that arises shortly after the executive arrives and stops after the executive leaves. Individual executives exhibit different proclivities toward tax aggressiveness. This variation in tax aggressiveness proclivity across executives affects their firms' tax aggressiveness in ways that cannot be explained by firm characteristics. Moreover, the evidence indicates that these executive effects can be economically large. Given the difficulty of explaining effective tax rates or other measures of tax aggressiveness, documenting that executives matter to their firms' effective tax rates is an important first step and contribution.

From the above description we have the following hypothesis:

Hypothesis 1: Firm size, profitability, and executive characteristics are negatively associated with corporate tax aggressiveness.

Hypothesis 2: Leverage is positively associated with corporate tax aggressiveness.

\section{Data and Research Methods}

This study focuses on corporate tax aggressiveness instead of a broad range of tax aggressiveness. Following Dyreng et al. (2008), the Cash ETR was utilized as an appropriate measure of tax aggressiveness. Dyreng et al. (2008) describe a low Cash ETR as "the ability to pay a low amount of cash taxes per dollar of pre-tax earnings over long time periods." Tax policies that avoid more taxes, and lead to lower Cash ETRs, could increase the firm's risk if the underlying activities that allow the firm to lower tax rates are inherently risky, or if lower tax rates are less sustainable than higher tax rates. On the other hand, the ability to avoid taxes has been shown to be stable over long time periods (Dyreng et al. 2008). In this case, the firm's tax rate would be fairly stable over time, and the riskiness of underlying activities may not be different from similar more highly taxed investments, in which case of tax aggressiveness activities would not be associated with firm risk.

Measurement of ExeC using EBITDA (Earning Before Income Tax, Depreciation, and Amortization), this measurement is in accordance with research conducted by Budiman \& Setyono (2012) used corporate risk (Corporate Risk) owned by a company. The greater earnings of the firm's earnings can indicate the greater risk. Regarding that notion, measuring company risk can be calculated through the standard deviation of EBITDA divided by the total assets of the company. This measurement is formulated as follows : 


$$
\left.R I S K=\quad \sum_{T-1}^{T}(E-1 / T) \sum_{T-1}^{T} \mathrm{E}\right){ }^{2}(T-1)
$$

The size of the company's risk can illustrate whether the executive belongs to a risk taker or risk averse category. It can be said as a risk taker if the risk of the company getting bigger, while the executives can be said as a risk averse if the risk of the company getting smaller.

Guire at al. (in Budiman \& Setyono, 2012) suggests that the size variable can be measured by using natural variable logarithm of total assets owned by the company.

\section{SIZE $=$ Ln Total Asset}

Leverage can explain the relationship between total assets with capital stock, or it can also show the use of debt to increase profit.

$$
\text { Debt to Equity Ratio }=\frac{\text { Total Liabilities }}{\text { Total Shareholdes'Equity }}
$$

Profitability consists of several ratios, one of them is ROA (Return On Assets). ROA is used because it can provide adequate measurement of the overall effectiveness of the company and ROA can also take into account profitability.

$$
\text { Return On Asset }=\frac{\text { Net Profit }}{\text { Total Aset }}
$$

Research sample was initially composed of 50 Property \& Real Estate companies listed on the Indonesia Stock Exchange (IDX) for an eight-year period from 2009 to 2016. The sample then was reduced to 27 groups after excluding certain groups for the lack of financial information, total of 215 observations. There were eight exercises chosen because they represent the latest data published by the listed Indonesia groups. Finally, all financial data used were collected manually from the consolidated financial statements and the annual reports published by the IDX. We use multiple regression model whose parameters will be estimated by SPSS method. The regression model is estimated as follow:

$$
\text { CASH ETR }_{i t}=\beta 0+\beta_{1} \text { RISK }_{i t}+\beta_{2} \operatorname{SIZE}_{i t}+\beta_{3} L E V_{i t}+\beta_{4} R O A_{i t}+\varepsilon
$$

Notation:

【CASH ETR】_it = Cash Effective Tax Rate of company $i$ in year $t$.

『RISK》_it $=$ Company risk (corporate risk) $\mathrm{i}$ in year $\mathrm{t}$.

【SIZE』_it = Total asset of company $i$ year $t$.

『LEV】_it = Company leverage $\mathrm{i}$ in year $\mathrm{t}$.

ROAit $=$ Net income in total asset for year $t$

$\beta 0=$ Constants

$\beta 1, \beta 2, \beta 3, \beta 4=$ OLS estimates on $\beta 1, \beta 2, \beta 3$, and $\beta 4$

$\varepsilon=$ error

\section{Results and Discussions}

Table 1 illustrates the descriptive statistics of the sample after the outliner data are omitted. In the table can be seen the average value (mean), the value of middle (median), maximum value, minimum value, and standard deviation. 
Table 1. Descriptive Statistics

\begin{tabular}{|c|c|c|c|c|c|}
\hline \multirow{2}{*}{ Statistik Deskriptif } & \multicolumn{5}{|c|}{ VARIABEL } \\
\cline { 2 - 6 } & RISK & CASH_ETR & SIZE & DER & ROA \\
\hline Mean & 0,08151 & 0,27154 & 22,1682 & 0,91005 & 0,06384 \\
\hline Median & 0,07331 & 0,22562 & 22,2471 & 0,84177 & 0,05169 \\
\hline Maximum & 0,34296 & 1,04521 & 24,5433 & 3,82753 & 0,31611 \\
\hline Minimum & 0,00125 & 0,00015 & 18,9316 & 0,06552 & 0,00115 \\
\hline Standar Dev. & 0,0553 & 0,19250 & 1,1481 & 0,60577 & 0,05049 \\
\hline
\end{tabular}

From the data in Table 1. it can be seen that all variables have a mean higher when compared with the standard devise of RISK variable has an average of 0.08151 with default devise of 0.0553 , then variable CASH_ETR with an average of 0.27154 has a standard deviation of 0.19250 . Then the Size, DER, and ROA variables that have a mean of 22.1682, 091005, and 0.06384 has a standard deviation of $1.1481,0.60577$, and 0.05049 . Nadhia et al (2014) in his article reveals that the average sample is lower than the standard deviation means that the sample can be used to represent all of its population.

Based on the data with the SPSS program, then the results obtained:

Table 2. Coefficients ${ }^{a}$

\begin{tabular}{|c|c|c|c|c|c|c|}
\hline \multirow{2}{*}{ Model } & \multicolumn{2}{|c|}{ Unstandardized Coefficients } & Standardized Coefficients & \multirow{2}{*}{ t } & \multirow{2}{*}{ Sig. } \\
\cline { 2 - 6 } \multicolumn{2}{c|}{1} & B & Std. Error & Beta & & \\
\cline { 2 - 6 } & (Constant) &,- 909 &, 741 & & $-1,227$ &, 221 \\
\cline { 2 - 6 } & RISK &,- 201 &, 068 &,- 185 & $-2,970$ &, 003 \\
\hline & SIZE &,- 088 &, 032 &,- 162 & $-2,783$ &, 006 \\
\hline & ROA &,- 317 &, 055 &,- 354 & $-5,777$ &, 000 \\
\hline & DER &, 459 &, 077 &, 350 & 5,936 &, 000 \\
\hline
\end{tabular}

It is presented that the constant value is -0.909 , the value of $b 1$ is -0.201 , the value of $b 2$ is -0.088 , the value of b3 is -0.317 , and the value of b4 is 0.459 . Based on the data in table 2 , it can be formed regression equation as follows:

$$
\text { CETR }=-0.909-0.201 \text { (RISK) }-0.088 \text { (SIZE) }-0.317(\text { ROA })+0.459(D E R)+\varepsilon
$$

From the regression equation above it can be explained that the executive characteristics have a negative influence or in other words $\mathrm{H}_{0}$ is accepted and $\mathrm{Ha}$ is rejected. This is stated by the coefficient $B$ in table 2 of -0.201 which means that it is smaller than 0 so it can be concluded that there is no positive influence between the characteristics of the executor on tax aggressiveness on Property and Real Estate Companies listed on the IDX. This proves that the higher the level of corporate risk, the smaller corporate tax aggressiveness. A higher level of corporate risk indicates that the executive character has more risk taker characteristics compared to a lower level of corporate risk indicating that the executive character has more risk averse character (Damayanti \& Susanto, 2015). Company size (size) has a coefficient of -0.088 and a significance value of $0.006>0.05$. From these results it can be concluded that the size of the company (size) has a negative effect on tax aggressiveness. The profitability variable has a coefficient of -0.317 and a significance value of $0.00<0.05$, from the results it can be concluded that profitability has a negative effect on tax aggressiveness. While the liquidity variable has a coefficient of 0.459 and a significance value of $0.000<0.05$, it can be concluded that liquidity has a positive effect on tax aggressiveness. This result is coherent with the research of Dewi \& Sari (2015) which states that the higher the company, the tax aggressiveness will be lower this is because the executives who are risk takers tend to present the financial statements as they are to see how far the performance has been done by the company, so causes tax aggressiveness to be low. This result is reinforced by the research of Mayta \& Sukartha (2016) in their article stating that executive characteristics proxied by the company's risk have a negative effect due to the characteristics of the 
executive tend to be risk averse, which is a character that does not like risk, so that the decision making does not result in high risk. However, the results of this study are not coherent with previous studies conducted by Budiman \& Setyono (2012), Damayanti \& Susanto, (2015), which state that there is a positive influence on executive characteristics on tax aggressiveness, this means that If the executive is increasingly a risk taker, the tax aggressiveness action will be greater. Company size has a negative effect. This result is coherent with Siregar \& Utama (in Hanum \& Zulaikha, 2013) which states that the larger the company, the lower the tax rate will be, this indicates that the larger the company, then the information contained in the final report must be very careful so that the report displayed is an accurate report and can avoid misstatement. Company profitability has a negative effect. These results are in line with the research conducted by Handayani, et al (2015) which states that ROA is an indicator of company's ability to generate profits so that ROA is an important factor in the imposition of income tax for the company. Thus the high value of ROA will be a mature tax planning so as to produce optimal taxes so that the tendency to conduct tax aggressiveness activities will decrease. From the explanation above it can be concluded that $\mathrm{H} 1$ is accepted, where Risk, Size, and Profitability have a negative effect on tax aggressiveness.

Furthermore, company leverage has a positive effect. This result is in line with research conducted by Hanum \& Zulaikha (2013) which states that the more debt is used to finance company activities, the better the effective tax rate generated by the company is marked by the lower effective tax rate because the interest cost is a deduction factor in taxes. From the explanation above, it can be concluded that $\mathrm{H} 2$ is accepted, where leverage has a positive effect on tax aggressiveness.

\section{Conclusions and Limitations}

In order to maximize the firm value, shareholders would like to minimize corporate tax payments net of the private costs of doing so; in other words they want the company to be optimally aggressive. However, there has been little rigorous empirical analysis of the benefits and costs to corporations of being tax aggressive. In this paper, the researchers attempt to fill this void particularly by investigating the executive characteristics, firm size, profitability and leverage of the firm. The data used is obtained from audited annual financial reports accessed from www.idx.go.id or from the websites of each company. The companies that were sampled in this study consist of 27 companies. To determine the effect of these variables, researchers used multiple regression analysis. The result of analysis reveal that the executive characteristics (Risk), firm size (Size), profitability (ROA) have a negative correlation on tax aggressiveness, while Leverage have positive correlation on tax aggressiveness.

However, some limitations are highlighted in this study. First, in this study the researchers only examined the variables of executive characteristics, company size, profitability, and leverage. In subsequent studies it is recommended that we examine other variables that can influence tax aggressiveness such as Fiscal Compensation Loss, Corporate Governance, Sales Growth, Company Age, family ownership, political connections, and other variables so that further research will expand what variables can affect corporate tax aggressiveness. Second, in this study the proxy used is the Cash Effective Tax Rate (CETR). For the next research it is recommended to use other proxies such as Book Tax Difference (BTD), or ten other proxies. Third, in this study the population was limited in to companies in the property and real estate sectors. therefore, For further research it is recommended to examine other sectors such as the consumer goods industry, the utilities and transportation sector, the financial sector, and the services and investment trade sector.

\section{References}

1. Adelina, Theresa. 2012. Influence of corporate characteristics and tax reform on tax aggressiveness in Manufacture Industry Listed on Indonesia Stock Exchange Year 2008-2010. Faculty of Economics University of Indonesia, Depok

2. Allingham, Michael G., dan Agnar Sandmo. 1972. Income Tax Evasion: A Theoretical Analysis. Journal of Public Economics 1:323-38 
3. Austin, Chelsea Rae and Wilson, Ryan J. 2015. Are Reputational Costs a Determinant of Tax Avoidance? ,2013 American Taxation Association Midyear Meeting: Tax Avoidance in an International Setting, Available at SSRN: https://ssrn.com/abstract=2216879 or http://dx.doi.org/10.2139/ssrn.2216879

4. Bankman, J. 2004.An academic's view of the tax shelter battle. In, Aaron, H.J., Slemrod J., Eds. The Crisis in Tax Administration. Brookings Institution, Washington, D.C., pp. 9-37.

5. Bond S, Bae, K. H., Kang, J. K., \& Kim, J. M. 2002. Tunneling or value added? Evidence from mergers by Korean business groups. The journal of finance, 57 (6), pp 2695-2740.

6. Budiman, Judi dan Setiyono. (2012). Pengaruh Karakteristik Eksekutif Terhadap Penghindaran Pajak (Tax Avoidance). Simposium Nasional Akuntansi XV. Universitas Lambung Mangkurat, Banjarmasin.

7. Christina, Silvy. 2017. The Effect of Tax Aggressiveness on Debt Policy with Independent Board as Moderating Variable, Pertanika Journal of Social Science and Humanities, Vol 25(S), pp 221-230.

8. Crocker, Keith J. and Joel Slemrod. 2005. Corporate Tax Evasion With Agency Costs," Journal of Public Economics, v89(9-10, Sep), 1593-1610.

9. Damayanti, Fitri \& Susanto, Tridahus. (2015). Pengaruh Komite Audit, Kualitas Audit, Kepemilikan Institusional, Risiko Perusahaan dan Return On Assets Terhadap Tax Avoidance. jurnal Bisnis dan Manajemen, Vol 5 (No. II), hal 187-206Danielova, A., \& Sarka, S. 2011. The effect of leverage on the tax-cut versus investment subsidy argument. Review of Financial Economics, 20(4), 123-129. http://dx.doi.org/10.1016/j.rfe.2011.10.001

10.Desai, Mihir A. and Dhammika Dharmapala. 2006. Corporate Tax Avoidance and High-Powered Incentives, Journal of Financial Economics, 79(1), pp 145-179.

11.Dewi, G. A., \& Sari, M. M. (2015). Pengaruh Insentif Eksekutif, Corporate Risk dan Corporate Governance pada Tax Avoidance. E-Jurnal Akuntansi Universitas Udayana, 50-67.

12.Dharmapala, Dhammika and Desai, Mihir A. .2009. Earnings management, corporate tax shelters, and book-tax alignment, HBS Finance Working Paper, No. 884812. Available at SSRN: http://dx.doi.org/10.2139/ssrn.884812

13.Dyreng, S., M. Hanlon, and E. Maydew. 2008. Long run corporate tax aggressiveness. The Accounting Review, 83(1), pp 61-82.

14.Dyreng, S., Hanlon, M. and Maydew, E. (2010) The Effects of Executives on Corporate Tax Avoidance. The Accounting Review, 85, 1163-1189.

15.Duff DG. 2009. Tax aggressiveness in the 21st Century. In: Evans C, Krever R, editors. Australian business tax reform in retrospect and prospect. Thomson

16.Ftouhi, K., Ayed, A., \& Zemzem, A. 2010. Tax planning and firm value: Evidence from European companies. International Journal of Economics and Strategic Management of Business Process, 4, pp 1-9.

17.Gallemore, J., Maydew, E., Thornock, J. 2014. The reputational costs of tax aggressiveness and the undersheltering puzzle. Contemporary Accounting Research, 31, pp 1103-1133.

18.Graham, J., Hanlon, M., Shevlin, T., Shroff, N. 2014. Incentives for tax planning and avoidance: Evidence from the field. The Accounting Review, 89, pp 991-1023.

19. Handayani, Cahyaning Dewi., Aris,Muhammad Abdul., Mujiyati. 2015. Pengaruh Return on Asset, Karakter Eksekutif, dan Dimensi Tata Kelola Perusahaan yang Baik Terhadap Tax Avoidance, Syariah Paper Accounting FEB UMS, ISSN 2460-0784, 427-439

20. Hanlon, M., Slemrod, J., 2009. What does tax aggressiveness signal? Evidence from stock price reactions to news about tax shelter involvement. Journal of Public Economics, 93, pp 126-141.

21.Hanlon, M., Heitzman, S., 2010. A review of tax research. Journal of Accounting and Economics, 50, pp127-178.

22.Hanum, H.R \& Zulaikha. 2013. Pengaruh Karakteristik Eksekutif Terhadap Effective Tax Rate. Diponogoro Journal Of Accounting.2(2).hlm.1-10

23. Mayta, Luh Putu, \& Sukartha, I Made, .2016. Pengaruh karakteristik eksekutif dan kepemilikan keluarga pada tax aggressiveness perusahaan. E-Jurnal Akuntansi Universitas Udayana, 17(1), pp 426-452. 
24.Modigliani, F., \& Miller, M. 1963. Corporate income taxes and the cost of capital: A correction. The American Economic Review, 53(3), pp 433-444.

25.Ngadiman \& Christiany, Puspitasari. 2014. Leverage influence, institutional ownership, and company size on tax aggressiveness in manufacturing sector listed on Indonesia Stock Exchange 2010-2012. e-Journal of Tarumanegara University, 18 (3), pp. 408-421

26. Orihara, Masanori.2015. Stock market listing and corporate tax aggressiveness: Evidence from legal reforms in squeeze out in Japan Policy Research Institute, Ministry of Finance, Japan. PRI Discussion Paper Series (No.15A-5)

27.Prawira, Ida Farida Adi. 2017. Corporate governance and tax aggressiveness, an evidence on manufacturing companies in Indonesia. International Journal of Accounting and Economic Studies (IJAES), Vol 5 (2), DOI: 10.14419/ijaes.v5i2.8132

28. Richardson, G., Taylor, G., Lanis, R. 2013a. The impact of board of director oversight characteristics on corporate tax aggressiveness: an empirical analysis. Journal of Accounting and Public Policy, 32 (3), pp 68-88.

29.Richardson, G., Taylor, G., \&Lanis, R. 2013b. Determinants of transfer pricing aggressiveness: Empirical evidence from Australian firms. Journal of Contemporary Accounting \& Economics, 9 (2), pp 136-150.

30.Sikka, P., \& Haslam, C. 2007. Transfer pricing and its role in tax aggressiveness and flight of apital: some theory and evidence. In Centre for global accountability, seminar seriesUniversity of Essex, $U K$.

31.Slemrod, J. 2001. A general model of the behavior response to taxation. International Tax and Public Finance, 8 (2), pp 119-128.

32.Slemrod, J., \& Wilson, J. D. 2009. Tax competition with parasitic tax havens. Journal of Public Economics, 93, pp 1261-1270.

33.Waworuntu, S.R, and Hadisaputra,R. 2016. Determinants of Transfer Pricing Aggressiveness in Indonesia, Petranika Journal of Social Science and Humanities, Vol 24(S), pp 95-110.

34.Wilson, R., 2009. An examination of corporate tax shelter participants. The Accounting Review, 84, pp 969-999. 